\title{
Naloxone evokes large-amplitude GnRH pulses in luteal-phase ewes*
}

\author{
R. J. E. Horton, J. T. Cummins $\dagger$ and I. J. Clarke \\ Medical Research Centre, Prince Henry's Hospital, St Kilda Road, Melbourne, Victoria 3004, and \\ $\dagger$ Department of Neurosurgery, St Vincent's Hospital, Fitzroy, Victoria 3065, Australia
}

\begin{abstract}
Summary. Ewes were sampled during the mid-late luteal phase of the oestrous cycle. Hypophysial portal and jugular venous blood samples were collected at 5-10 min intervals for a minimum of $3 \mathrm{~h}$, before i.v. infusions of saline $(12 \mathrm{ml} / \mathrm{h} ; \mathrm{N}=6)$ or naloxone $(40 \mathrm{mg} / \mathrm{h} ; \mathrm{N}=6)$ for $2 \mathrm{~h}$. During the 2 -h saline infusion $2 / 6$ sheep exhibited a $\mathrm{GnRH} / \mathrm{LH}$ pulse; $3 / 6$ saline infused ewes did not show a pulse during the 6-8-h portal blood sampling period. In contrast, large amplitude $\mathrm{GnRH} / \mathrm{LH}$ pulses were observed during naloxone treatment in $5 / 6$ ewes. The mean ( \pm s.e.m.) amplitude of the LH secretory episodes during the naloxone infusion $(1.07 \pm 0.11 \mathrm{ng} / \mathrm{ml})$ was significantly $(P<0.05)$ greater than that before the infusion in the same sheep $(0.54 \pm 0.15 \mathrm{ng} / \mathrm{ml})$. Naloxone significantly $(P<0.005)$ increased the mean GnRH pulse amplitude in the $5 / 6$ responding ewes from a pre-infusion value of $0.99 \pm 0.22 \mathrm{pg} / \mathrm{min}$ to $4.39 \pm 1.10 \mathrm{pg} / \mathrm{min}$ during infusion. This episodic GnRH secretory rate during naloxone treatment was also significantly $(P<0.05)$ greater than in the saline-infused sheep $(1.53 \pm 0.28 \mathrm{pg} / \mathrm{min})$. Plasma FSH and prolactin concentrations did not change in response to the opiate antagonist.

Perturbation of the endogenous opioid peptide system in the ewe by naloxone therefore increases the secretion of hypothalamic GnRH into the hypophysial portal vasculature. The response is characterized by a large-amplitude $\mathrm{GnRH}$ pulse which, in turn, causes a large-amplitude pulse of LH to be released by the pituitary gland.
\end{abstract}

\section{Introduction}

Neuromodulation of gonadotrophin secretion by the endogenous opioid peptides may be one way that gonadal steroids produce feedback effects on the hypothalamo-pituitary axis. Whilst ovarian steroids can modulate gonadotrophin secretion at the hypothalamic and pituitary levels (Goodman \& Karsch, 1980; Clarke \& Cummins, 1984, 1985a), there is still some uncertainty whether the opioid peptides act at one or both of these sites.

The high concentrations of $\beta$-endorphin in the hypophysial portal blood of rats (Sarkar \& Yen, 1985), monkeys (Wardlaw et al., 1980) and sheep (Gordon et al., 1987) indicate that opioids may act directly on the gonadotrophs. Recent in-vitro studies showed that continued exposure of pituitary cells to opioids could suppress basal LH output (Cacicedo \& Sanchez-Franco, 1986; Blank et al., 1986; Chao et al., 1986) and GnRH-stimulated LH release (Blank et al., 1986; Chao et al., 1986). Others have found that neither naloxone nor opiate agonists had any effect on short-term LH secretion from rat hemipituitaries in vitro (Shaar et al., 1977; Cicero et al., 1979; Grandison et al., 1980; Wiesner et al., 1984). Morphine did not alter the LH response to GnRH pulses in stalksectioned monkeys (Ferin et al., 1982). Whether or not opioid peptides can directly inhibit the

* Reprint requests to Mr R. J. E. Horton. 
secretion of the gonadotrophins presumably depends upon the presence or absence of opiate receptors within the anterior pituitary. Opiate receptors are present in the anterior pituitary of the rat albeit at low levels (Simantov \& Snyder, 1977; Atweh \& Kuhar, 1983; Lightman et al., 1983); but are not present in the anterior pituitary of the monkey (Wamsley et al., 1982) or the sheep (J. H. Boublik \& I. J. Clarke, unpublished observations).

In contrast to the pituitary gland, there is little doubt that the hypothalamus is an integral locus for opioid-induced changes in gonadotrophin secretion, since intrahypothalamic implantation of naloxone (Kalra, 1981) or injection of antisera to $\beta$-endorphin or dynorphin into the mediobasal hypothalamus (Schulz et al., 1981) stimulates $\mathrm{LH}$ release. In addition, the naloxone-induced increase in LH can be blocked by pretreating rats with a GnRH antagonist (Blank \& Roberts, 1982). Naloxone increased GnRH secretion from the mediobasal hypothalamus in vitro (Wilkes \& Yen, 1981; Rasmussen et al., 1983; Leadem et al., 1985).

In vivo, naloxone increases (Blank et al., 1985) GnRH secretion in male rats and morphine suppresses (Ching, 1983) the preovulatory GnRH surge in the hypophysial portal blood of anaesthetized rats, but concomitant LH measurements were not possible because the animals were stalksectioned to obtain the samples. The present study was undertaken to determine whether naloxone affects pituitary LH secretion via an effect on GnRH secretion in the conscious ewe.

\section{Materials and Methods}

Animals. A harnessed vasectomized ram was introduced into a flock of mature Corriedale ewes to detect the onset of oestrus. Ewes weighing between 30 and $35 \mathrm{~kg}$ were selected for sampling during the mid-late luteal phase (Days 7-13) of the oestrous cycle. During the experiment the ewes were kept in individual pens, fed a maintenance ration of lucerne chaff, allowed water ad libitum and subjected to normal patterns of daylight.

Surgical procedure. The ewes were prepared for portal blood sampling as previously described by Clarke \& Cummins (1982, 1985a) 1-2 days before experimentation. Briefly, the hypothalamo-hypophysial portal vessels coursing along the anterior face of the pituitary gland were surgically exposed. An artificial sinus was made around the anterior face of the pituitary, into which two 12-gauge stainless-steel guide tubes were introduced. One of these guide tubes was positioned on the floor of the cavity for the subsequent collection of portal blood. The other was directed towards the portal vessels on one side of the pituitary gland, through which a stillette would be used to puncture the portal vasculature. After surgery the artificial sinus was routinely flushed via the guide tubes every $6-12 \mathrm{~h}$ with sterile saline to remove blood clots and fibrin deposits.

Portal blood collection procedure. The ewes were given intravenous bolus injections of $25000 \mathrm{U}$ sodium heparin at 07:00, 08:00 and 09:00 $\mathrm{h}$. In addition the animals were placed on a heparin drip of $\sim 7500 \mathrm{U} / \mathrm{h}$ and given further bolus injections of $25000 \mathrm{U}$ every $2 \mathrm{~h}$ until the conclusion of the experiment.

Beginning at 08:00 h peripheral blood samples were collected every $10 \mathrm{~min}$ via an indwelling jugular cannula. At 09:00 $\mathrm{h}$ the portal blood vessels were lesioned. Portal blood was collected under continuous suction through a polyethylene cannula (i.d. $1.57 \mathrm{~mm}$, o.d. $2.08 \mathrm{~mm}$ ) inserted into the lower guide tube. Thereafter portal blood sampling began when the flow rate had reached $1.5 \mathrm{ml}$ per 10 -min interval. Portal blood was aspirated continuously into tubes containing $0.5 \mathrm{ml} 5 \mathrm{~mm}$-bacitracin (Sigma; dissolved in $0.9 \%(\mathrm{w} / \mathrm{v}) \mathrm{NaCl}$, saline) and kept in an ice bath. A fresh collection tube was placed on the aspiration apparatus every 5 or 10 min depending on the rate of collection of portal blood. Concomitant samples of jugular blood $(6 \mathrm{ml})$ were obtained immediately after changing to a fresh portal collection tube.

Measurements of volume and haematocrit were made for jugular and portal blood samples. The samples were kept in an ice bath until centrifugation at $4^{\circ} \mathrm{C}$. Plasma was decanted and stored at $-15^{\circ} \mathrm{C}$ until assayed for $\mathrm{GnRH}$, LH, FSH, prolactin and progesterone.

Naloxone infusion. Portal blood samples were taken for a minimum of $3 \mathrm{~h}$ before administration of naloxone hydrochloride (40 mg/h, $\mathbf{N}=6$ ) (Sterling-Winthrop, Guildford, Surrey, U.K.) or vehicle (saline; $N=6$ ). Infusions were made at a rate of $12 \mathrm{ml} / \mathrm{h}$ for $2 \mathrm{~h}$ using a Braun Unita 1A pump (B. Braun, Melsungen, FRG) holding a 50-ml glass syringe. Sampling continued for $1-3 \mathrm{~h}$ after the end of the infusion period.

Autopsy. At the conclusion of each portal bleed the ewe was killed by cervical dislocation. The top of the head was opened and the brain and pituitary were removed to ascertain the site of the lesion in the pituitary portal vessels. Finally the ovaries were inspected for the presence of corpora lutea.

Hormone analysis. GnRH was measured in duplicate in acidified methanol extracts of portal plasma using the method of Jonas et al. (1975). Recovery of the GnRH standard added to control plasma and determined in each of 12 GnRH assays averaged $66 \cdot 3 \pm 3.4 \%$ (mean \pm s.e.m.); sample values were corrected for recovery. Assay sensitivity was $0 \cdot 1-0 \cdot 2 \mathrm{pg} /$ tube with an intra-assay coefficient of variation $(\mathrm{CV})$ of $<10 \%$ over the range $1 \cdot 1-43 \cdot 4 \mathrm{pg} / \mathrm{ml}$. The 
between-assay CV of 2 plasma pools was $17 \%$ at $28.8 \mathrm{pg} / \mathrm{ml}$ and $16 \%$ at $16.5 \mathrm{pg} / \mathrm{ml}$. GnRH is expressed in terms of $\mathrm{pg} / \mathrm{min}$ rather than $\mathrm{pg} / \mathrm{ml}$ as previously described (Karsch et al., 1987) since the former takes account of blood flow variations. As bacitracin was added to the portal collection tubes a sample of this was included in each GnRH assay. The bacitracin value was subtracted from the portal plasma GnRH assay value. As the GnRH baseline values were often equal to the bacitracin values, most of the $\mathrm{GnRH}$ profiles had a baseline occurring at $0 \mathrm{pg} / \mathrm{min}$.

Plasma LH concentrations were measured using the methods of Lee et al. (1976). In 11 assays the sensitivity was $0 \cdot 2-0.4 \mathrm{ng} / \mathrm{ml}$. The intra-assay $\mathrm{CV}$ was $<10 \%$ over the range $1.8-66 \mathrm{ng} / \mathrm{ml}$ and the between-assay $\mathrm{CV}$ was $18 \%$ at $6.1 \mathrm{ng} / \mathrm{ml}, 13 \%$ at $27.2 \mathrm{ng} / \mathrm{ml}$ and $12 \%$ at $40.3 \mathrm{ng} / \mathrm{ml}$.

Plasma FSH concentrations were measured using the method of Bremner et al. (1980). In 6 assays the sensitivity was $1 \cdot 1-1.8 \mathrm{ng} / \mathrm{ml}$. The intra-assay $\mathrm{CV}$ was $<10 \%$ over the range $7 \cdot 1-460 \mathrm{ng} / \mathrm{ml}$ and the between-assay $\mathrm{CV}$ was $6 \%$ at $17.7 \mathrm{ng} / \mathrm{ml}, 7 \%$ at $29.1 \mathrm{ng} / \mathrm{ml}$ and $6 \%$ at $75.3 \mathrm{ng} / \mathrm{ml}$.

Plasma prolactin concentrations were measured using the method of Clarke et al. (1982). In 6 assays the sensitivity was $1 \cdot 0-1 \cdot 8 \mathrm{ng} / \mathrm{ml}$. The intra-assay $\mathrm{CV}$ was $<10 \%$ over the range $5 \cdot 4-140 \mathrm{ng} / \mathrm{ml}$ and the between-assay $\mathrm{CV}$ was $10 \%$ at $5.5 \mathrm{ng} / \mathrm{ml}$ and $8 \%$ at $21.4 \mathrm{ng} / \mathrm{ml}$.

Progesterone was measured in petroleum ether extracts of plasma according to the procedure of Hossain $e t$ al. (1979). The sensitivity was $0.1 \mathrm{ng} / \mathrm{ml}$.

Data analysis. A pulse was defined as occurring if the assay value of a given sample exceeded the assay value of the previous sample by at least three times the standard deviation. Student's $t$ tests (paired or unpaired as appropriate) were used to make statistical comparisons for the GnRH and LH pulse amplitudes. The mean prolactin and FSH concentrations during the naloxone infusion were compared to those during the saline infusion by using a two-way analysis of variance.

\section{Results}

The mean ( \pm s.e.m.) plasma concentration of progesterone at the time of sampling was $2.07 \pm$ $0.47 \mathrm{ng} / \mathrm{ml}$. Two sheep in the naloxone-treated group had low luteal-phase concentrations of progesterone in plasma $(0.4 \mathrm{ng} / \mathrm{ml}, 0.8 \mathrm{ng} / \mathrm{ml})$, as did one sheep in the saline-treated control group $(0.8 \mathrm{ng} / \mathrm{ml})$. Individual progesterone values are indicated on the figures.

Figure 1(a-f) shows that, after a preinfusion portal blood sampling period of at least $3 \mathrm{~h}$, naloxone induced a large-amplitude GnRH response in 5/6 ewes. The mean ( \pm s.e.m.) GnRH pulse amplitude during treatment with naloxone $(4.39 \pm 1 \cdot 10 \mathrm{pg} / \mathrm{min})$ was significantly $(P<0.005)$ greater than the preinfusion value $(0.99 \pm 0.22 \mathrm{pg} / \mathrm{min})$ in the same sheep and also significantly $(P<0.05)$ greater than the mean GnRH pulse amplitude of all the peaks in the $3 / 6$ saline-infused sheep that had GnRH pulses $(1.53 \pm 0.28 \mathrm{pg} / \mathrm{min})$. In only $2 / 6$ saline-treated animals (Fig. $2 \mathrm{a}, \mathrm{b})$ were $\mathrm{GnRH}$ pulses observed during the 2 -h infusion period. Two of the 5 naloxone-responsive sheep (Fig. Ib, c) exhibited a large-amplitude GnRH pulse after the 2-h infusion period. The amplitudes of these 2 pulses were greater (Fig. $1 \mathrm{~b}: 2.61 \mathrm{pg} / \mathrm{min}$; Fig. $1 \mathrm{c}: 6.74 \mathrm{pg} / \mathrm{min}$ ) than those of pulses observed before the infusion (Fig. 1b: $0.20 \mathrm{pg} / \mathrm{min}$; Fig. 1c: $2.07 \mathrm{pg} / \mathrm{min}$ ) in the same sheep. In $3 / 5$ sheep responding to naloxone, $2 \mathrm{GnRH}$ pulses were observed during the infusion period (Fig. lb, c, d).

The $\mathrm{LH}$ pulses were temporally related to the GnRH pulses in the saline- and naloxone-treated animals. In some cases (8/29) LH pulses were not detected with GnRH pulses and in $3 / 25$ cases $\mathrm{LH}$ pulses occurred without GnRH pulses. The mean ( \pm s.e.m.) LH pulse amplitude during the naloxone infusion was $1.07 \pm 0.11 \mathrm{ng} / \mathrm{ml}$. This was significantly $(P<0.05)$ greater than the mean pulse amplitude before the infusion in the same sheep $(0.54 \pm 0.15 \mathrm{ng} / \mathrm{ml})$, but was not significantly different from that in the saline-infested sheep $(0 \cdot 69 \pm 0 \cdot 14 \mathrm{ng} / \mathrm{ml})$.

Neither FSH nor prolactin changed in response to naloxone (Fig. 3a, b). As jugular blood sampling began at $08: 00 \mathrm{~h}$, prolactin secretion fell from an early morning peak during the diurnal rhythm to level out to a daytime trough by 11:00-12:00 h; this occurred in controls and naloxonetreated ewes.

\section{Discussion}

We have demonstrated that naloxone evokes large-amplitude GnRH pulses in conscious ewes during the luteal phase of the oestrous cycle; all except one treated ewe showed this type of GnRH response. In addition to an effect on GnRH pulse amplitude the results suggest that naloxone 
(a)

Ewe $359(2.8 \mathrm{ng} / \mathrm{ml})$

Naloxone

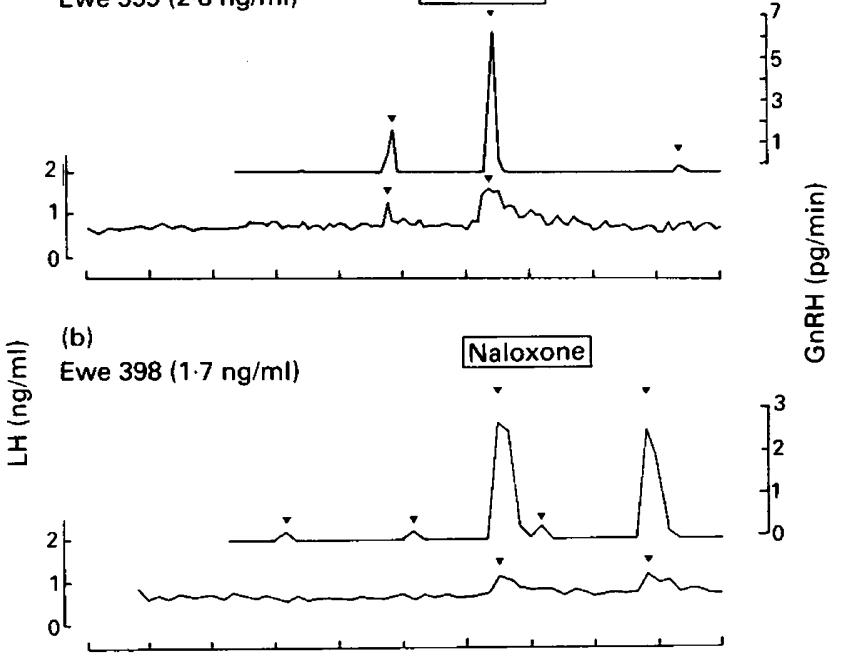

(c)

Ewe $376(0.4 \mathrm{ng} / \mathrm{ml})$

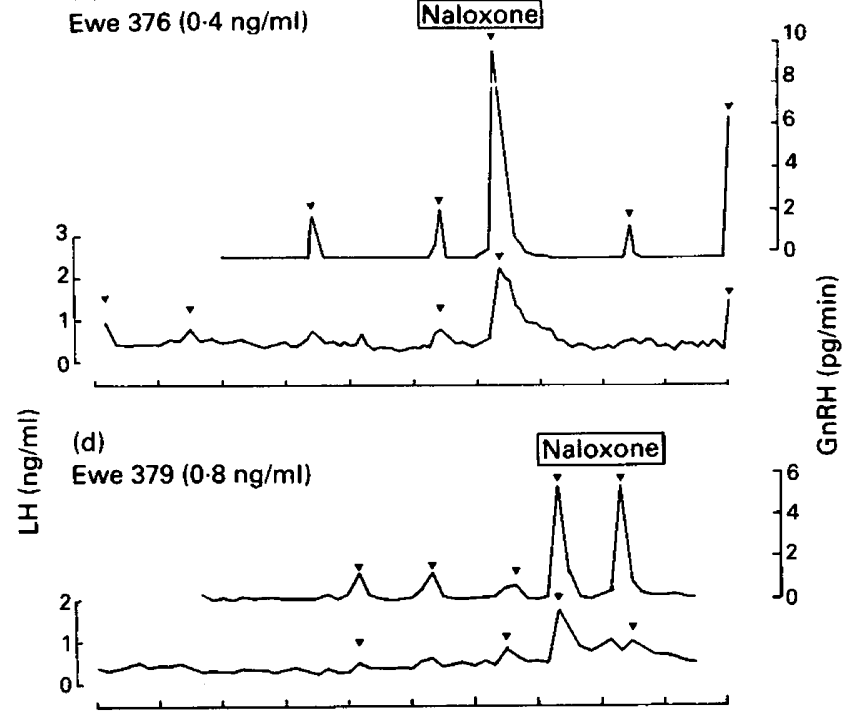

(e)
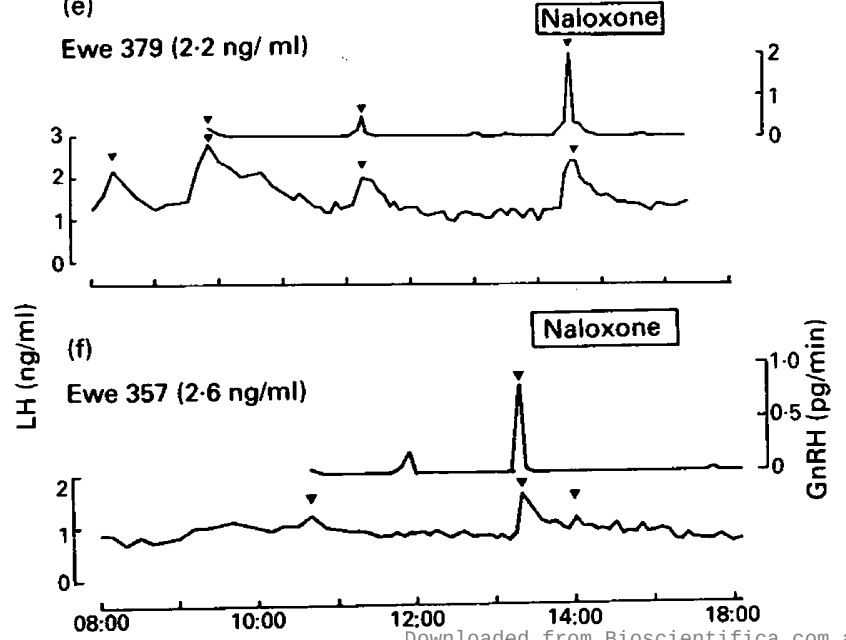

Time of day (h) from Bioscientifica.com at $04 / 26 / 2023$ 08:22:27AM 
(a)

Ewe $370(2 \cdot 2 \mathrm{ng} / \mathrm{ml})$
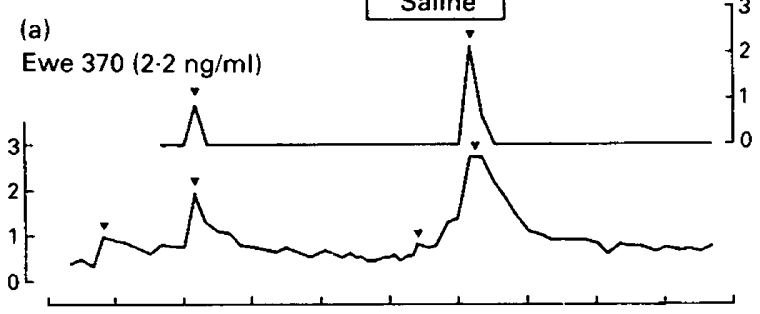

Saline

(b)

Ewe $384(0.8 \mathrm{ng} / \mathrm{ml})$
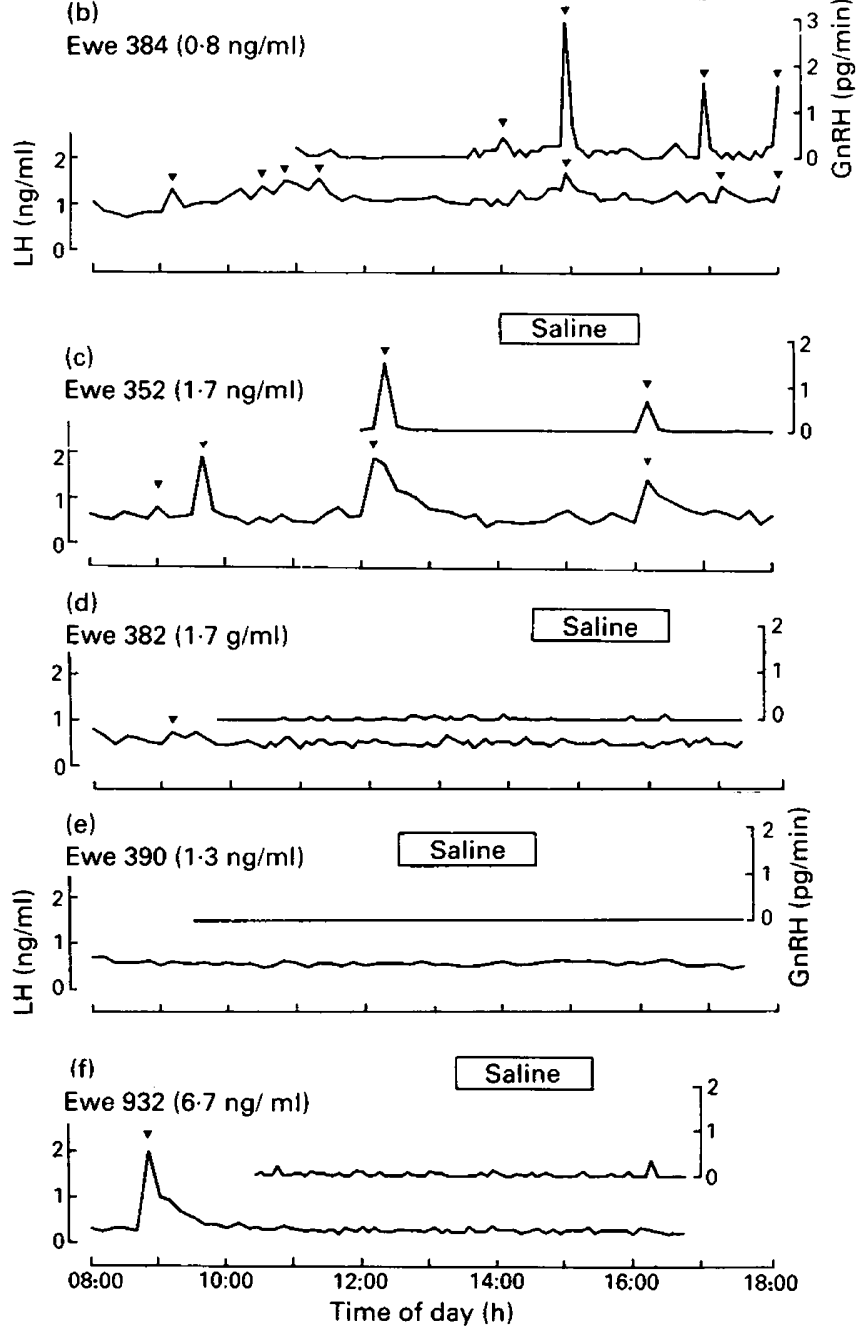

Fig. 2. Effect of a 2-h infusion of vehicle (saline) on the GnRH (upper panel) and LH (lower panel) secretory profiles for 6 luteal-phase ewes $(a-f)$. The sheep numbers are shown at the top left hand corner with (in parentheses) are the progesterone concentrations for each ewe determined from plasma samples obtained on the day of the experiment. A pulse is denoted by $\boldsymbol{\nabla}$.

Fig. 1. Effect of a $2-\mathrm{h}$ infusion of naloxone $(40 \mathrm{mg} / \mathrm{h})$ on the $\mathrm{GnRH}$ (upper panel) and $\mathrm{LH}$ (lower panel) secretory profiles for 6 luteal-phase ewes $(a-f)$. The sheep numbers are shown with (in parentheses) the progesterone concentrations for each ewe determined from plasma samples obtained on the day of the experiment. A pulse is denoted by $\boldsymbol{\nabla}$. 
(a)

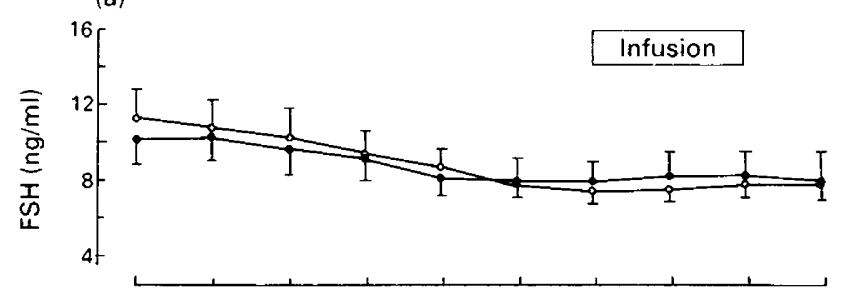

(b)

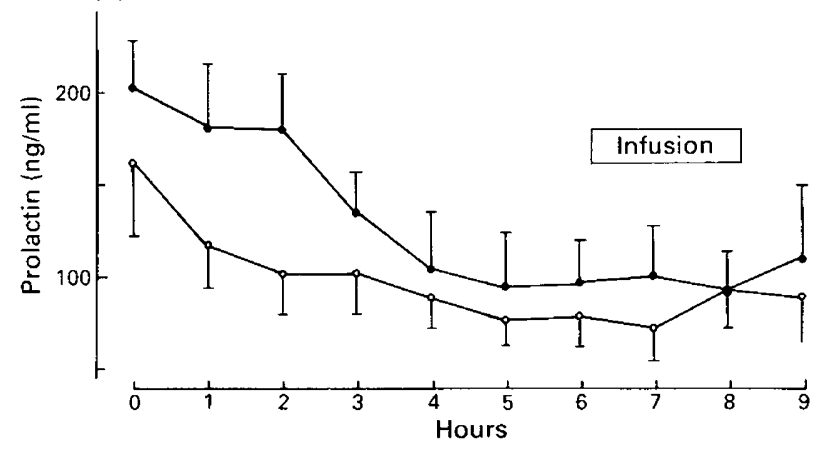

Fig. 3. FSH (a) and prolactin (b) secretory profiles during an infusion of naloxone ( $\bullet$ ) or saline $(O)$. Each point represents the mean \pm s.e.m. for 6 animals.

evokes a new pulse. Of the 5 naloxone-responsive ewes, 3 exhibited $2 \mathrm{GnRH}$ pulses during the 2-h infusion period, whereas none of the saline-treated ewes had more than one GnRH pulse and only $2 / 6$ ewes had a single GnRH pulse during the same period. It therefore appears that the central opioid peptide system may be involved in the regulation both of GnRH pulse amplitude and pulse frequency. Our results extend the findings of several recent studies on the consequent changes in GnRH secretion during naloxone treatment in rats and rabbits. In anaesthetized stalk-sectioned rats morphine decreased the magnitude of the pro-oestrous surge (Ching, 1983) and naloxone increased the mean portal concentrations of GnRH in male rats (Blank et al., 1985). Since in both of these studies the pituitary stalk was transected, concomitant measurements of LH secretion were not possible, as they were in the present study. Orstead \& Spies (1986) used the push-pull cannulation procedure to show that an infusion of naloxone into the medio-basal hypothalamus stimulated LH secretion in ovariectomized rabbits via the secretion of GnRH, but had no effect in ovary-intact rabbits. In addition, Kesner et al. (1986) found that morphine inhibited hypothalamic multiple-unit activity and LH pulses in ovariectomized monkeys and this was reversed by naloxone. On the other hand, naloxone alone had no effect. These contrast with numerous other studies, which demonstrated an ovarian steroid requirement for the naloxone-induced changes in LH secretion in the rat (Bhanot \& Wilkinson, 1984; Petraglia et al., 1984), monkey (Ferin et al., 1982), sheep (Brooks et al., 1986a) and human (Foresta et al., 1983; Shoupe et al., 1985). Our data generally agree with results obtained with ovary-intact animals.

Although regular mating checks were made to select mid-late luteal-phase ewes, 3/12 of the sheep studied had progesterone concentrations below the normal range for the luteal phase (Figs 1c, 1d \& 2b). In spite of this the 2 ewes that were given naloxone and had low plasma progesterone values still exhibited GnRH responses. Whilst these results appear to differ from those of Malven $e t$ al. (1984), which indicate the requirement for luteal-phase plasma progesterone concentrations to obtain an LH response to naloxone in sheep, they concur with those of Brooks et al. (1986b) who found that naloxone increased both LH pulse frequency and amplitude in follicular-phase ewes. 
Collectively these data suggest that the endogenous opioid peptides may tonically inhibit GnRH secretion during both the luteal and follicular stages of the sheep oestrous cycle. In contrast, naloxone increased LH pulse frequency in the luteal but not the follicular phase of women (Moult et al., 1981) and monkeys (Van Vugt et al., 1983). It is possible that sheep are different from monkeys and humans in their ability to respond to naloxone during the follicular phase of the oestrous/menstrual cycle. Although there are differences between these studies and ours, the dose and mode of administration of the drug may have contributed to the differing results. Whilst there are numerous studies of the rat, comparing the mean concentrations of $\mathrm{LH}$ before and after the administration of an opiate antagonist, we are not aware of any studies in which prolonged continuous blood sampling has enabled comparisons of pulse frequency and amplitude.

A consistent feature of many previous studies is that some animals/subjects that are given naloxone fail to show any $\mathrm{LH}$ response. In the present study, 1/6 naloxone-treated ewes did not show a GnRH/LH response. On the other hand, 2 of the naloxone-responsive ewes had a largeamplitude GnRH response after the 2-h infusion; these may be attributed to the ongoing effects of the opiate antagonist which has a relatively long circulating half-life of $90 \mathrm{~min}$ in humans (Fishman et al., 1973). Brooks et al. (1986b) also noted that the ability of naloxone to increase LH secretion in Suffolk-cross ewes varied, and further showed that there was no dose-response relationship between 25 and $100 \mathrm{mg} / \mathrm{h}$. Similarly, Van Vugt et al. (1983) demonstrated that only $60 \%$ of lutealphase monkeys had an $\mathrm{LH}$ response to naloxone. Finally, chronic treatment of rams with naloxone led to a loss of responsiveness after 3 days (Ebling \& Lincoln, 1985).

These variable responses raise some important questions about the physiological significance of the role that endogenous opioid peptides may have in regulating GnRH secretion. Do the central opioidergic neurones directly participate in the gonadal steroid feedback on the GnRH secretory apparatus, or is there merely some facilitatory role to enhance other means of feedback? For opioids and their antagonists to modify $\mathrm{GnRH} / \mathrm{LH}$ secretion there appears to be a requirement for gonadal steroids (Ferin et al., 1982; Bhanot \& Wilkinson, 1983, 1984; Petraglia et al., 1984), but this does not necessarily mean that the endogenous opioid peptide system is obligatory for gonadal steroid feedback on the hypothalamo-pituitary axis. On the other hand several recent reports suggest that gonadal steroids are not essential for an opioid effect on $\mathrm{GnRH} / \mathrm{LH}$ release (Leadem $e t$ al., 1985; Piva et al., 1986). It is well known that neuroactive messengers other than the opioids (for example, substance P, VIP, neuropeptide Y and catecholamines; Dees et al., 1985; Alexander et al., 1985; Kalra, 1985) are involved in the regulation of $\mathrm{GnRH} / \mathrm{LH}$ secretion and that these may be true neurotransmitters rather than neuromodulators. Variation between animals/subjects in responsiveness to naloxone may serve to highlight the fact that there is a large number of neuronal inputs to the GnRH system. The functioning of this system and the perception of feedback signals may not require all of these inputs to be operative.

FSH secretion did not change in response to a transient elevation in the GnRH secretory pattern during treatment with naloxone. This was expected since FSH does not appear to be acutely regulated by GnRH in the sheep (Clarke \& Cummins, 1985b). Other work in the rat (Sirinanthsinghji \& Martini, 1985; Piva et al., 1985), monkey (Van Vugt et al., 1983) and human (Foresta et al., 1983; Snowden et al., 1984) has also indicated that FSH is unresponsive to naloxone treatment, perhaps for similar reasons. However, Ropert et al. (1981) have shown that FSH does respond to an infusion of naloxone in women.

Before the infusion period, prolactin decreased from an elevated value to reach a steady state after $4 \mathrm{~h}$ of sampling, by 11:00-12:00 h. This pattern of prolactin secretion was probably due to, firstly, the diurnal rhythmicity of this pituitary hormone (Lamming et al., 1974) and, secondly, the stress-induced release when the sheep were prepared for portal blood sampling. Nevertheless, our observation that naloxone failed to change prolactin secretion may suggest that, unlike the GnRH/ LH system, neural mechanisms regulating prolactin secretion in the sheep do not involve endogenous opioid peptides in this species. Similarly, prolactin secretion in the rat was unaffected when naloxone was given systemically (Martin et al., 1979; Mioduszewski et al., 1982) and intraventricularly (Guidici 
et al., 1984; Limonta et al., 1986). On the other hand, some studies have shown that exogenous opioids stimulate prolactin secretion in rats (Meites et al., 1979; Morley, 1981; Leadem \& Kalra, 1985). Further work is required with sheep to determine whether exogenous opiates release prolactin as they do in the rat. Whilst prolactin secretion may not be tonically stimulated by the opioid peptides, these neuromodulators may still be capable of releasing prolactin under certain pharmacological conditions. It remains to be established whether this has a physiological counterpart.

In conclusion, these results demonstrate that the naloxone-induced increase in LH secretion is mediated centrally, through stimulating the release of hypothalamic $\mathrm{GnRH}$ into the hypophysial portal circulation. The response in these conscious ewes was characterized by a large-amplitude GnRH pulse. Neither FSH nor prolactin changed in response to naloxone.

We thank Mr B. Doughton, Mr T. Gill, Ms K. Burman and Miss L. Cavanagh for expert technical assistance; Mrs J. Williams and Ms R. Redman for preparation of the manuscript; the Director of the Animal Research Institute, Werribee, for the use of the excellent animal and laboratory facilities; and NIH and Dr L. E. Reichert Jr for RIA standards. This work was supported by the National Health and Medical Research Council of Australia.

\section{References}

Alexander, M.J., Clifton, D.K. \& Steiner, R.A. (1985) Vasoactive intestinal polypeptide effects a central inhibition of pulsatile luteinizing hormone secretion in ovariectomized rats. Endocrinology 117, 2134-2139.

Atweh, S.F. \& Kuhar, M.J. (1983) Distribution and physiological significance of opioid receptors in the brain. Br. med. Bull. 39, 47-52.

Bhanot, R. \& Wilkinson, M. (1983) Opiatergic control of gonadotropin secretion during puberty in the rat: a neurochemical basis for the hypothalamic 'gonadostat'? Endocrinology 113, 596-603.

Bhanot, R. \& Wilkinson, M. (1984) The inhibitory effect of opiates on gonadotrophin secretion is dependent upon gonadal steroids. $J$. Endocr. 102, 133-141.

Blank, M.S. \& Roberts, D.L. (1982) Antagonist of gonadotropin-releasing hormone blocks naloxoneinduced elevations in serum luteinizing hormone. Neuroendocrinology 35, 309-312.

Blank, M.S., Ching, M., Catt, K.J. \& Dufau, M.L. (1985) Inhibition of gonadotropin releasing hormone release as the basis of pituitary-gonadal dysfunction during treatment with 4-aminopyrazolo-(3,4-d)-pyrimidine. Endocrinology 116, 1778-1783.

Blank, M.S., Fabbri, A., Catt, K.J. \& Dufau, M.L. (1986) Inhibition of luteinizing hormone release by morphine and endogenous opiates in cultured cells. Endocrinology 118, 2097-2101.

Bremner, W.J., Findlay, J.K., Lee, V.W.K., de Kretser, D.M. \& Cumming, I.A. (1980) Feedback effects of the testis on pituitary responsiveness to LH-RH infusions in the ram. Endocrinology 106, 329-336.

Brooks, A.N., Haynes, N.B., Yang, K. \& Lamming, G.E. (1986a) Ovarian steriod involvement in endogenous opioid modulation of LH secretion on seasonally anoestrous mature ewes. J. Reprod. Fert. 76, 709-715.

Brooks, A.N., Lamming, G.E., Lees, P.D. \& Haynes, N.B. (1986b) Opioid modulation of LH secretion in the ewe. J. Reprod. Fert. 76, 693-708.
Cacicedo, L. \& Sanchez Franco, F. (1986) Direct action of opioid peptides and naloxone on gonadotropin secretion by cultured rat anterior pituitary cells. Life Sci. 38, 617-625.

Chao, C.C., Moss, G.E. \& Malven, P.V. (1986) Direct opioid regulation of pituitary release of bovine luteinizing hormone. Life Sci. 39, 527-534.

Ching, M. (1983) Morphine suppresses the proestrous surge of GnRH in pituitary portal plasma of rats. Endocrinology 112, 2209-2211.

Cicero, T.J., Schainker, B.A. \& Meyer, E. R. (1979) Endogenous opioids participate in the regulation of the hypothalamic-pituitary-luteinizing hormone axis and testosterone negative feedback control of luteinizing hormone. Endocrinology 104, 1286-1291.

Clarke, I.J. \& Cummins, J.T. (1982) The temporal relationship between gonadotropin releasing hormone $(\mathrm{GnRH})$ and luteinizing hormone $(\mathrm{LH})$ secretion in ovariectomized ewes. Endocrinology 111, 1737-1739.

Clarke, I.J. \& Cummins, J.T. (1984) Direct pituitary effects of estrogen and progesterone on gonadotropin secretion in the ovariectomized ewe. Neuroendocrinology 39, 267-274.

Clarke, I.J. \& Cummins, J.T. (1985a) Increased gonadotrophin-releasing hormone pulse frequency associated with estrogen induced luteinizing hormone surges in ovariectomized ewes. Endocrinology 116, 2376-2383.

Clarke, I.J. \& Cummins, J.T. (1985b) GnRH pulse frequency determines $\mathrm{LH}$ pulse amplitude by altering the amount of releasable $\mathrm{LH}$ in the pituitary gland. $J$. Reprod. Fert. 73, 425-431.

Clarke, I.J., Mitchelhill, K., Zachariah, E., Findlay, J.K. \& Funder, J.W. (1982) Analysis of androgen action on pituitary gonadotropin and prolactin secretion in ewes. Biol. Reprod. 26, 777-786.

Dees, W.L., Skelley, C.W. \& Kozlowski, G.P. (1985) Central effect of an antagonist and an antiserum to 
substance $\mathbf{P}$ on serum gonadotrophin and prolactin secretion. Life Sci. 37, 1627-1631.

Ebling, F.J.P. \& Lincoln, G.A. (1985) Endogenous opioids and the control of seasonal LH secretion in Soay rams. J. Endocr. 107, 341-353.

Ferin, M., Wehrenberg, W.B., Lam, N.Y., Alston, E.J. \& Vande Wiele, R.L. (1982) Effects and site of action of morphine on gonadotropin secretion in the female rhesus monkey. Endocrinology 111, 1652-1656.

Fishman, J., Roffberg, H. \& Hellman, L. (1973) Disposition of naloxone-7,8- ${ }^{3} \mathrm{H}$ in normal and narcoticdependent men. J. Pharm. exp. Therap. 187, 575-580.

Foresta, C., Marra, S., Federspil, G. \& Scandellari, C. (1983) Effects of naloxone on gonadotropin secretion in castrated young males before and after testosterone treatment. Horm. Metab. Res. 15, 567-568.

Giudici, D., D'Urso, R., Falaschi, P., Negri, L., Melchiorri, P. \& Motta, M. (1984) Dermorphin stimulates prolactin secretion in the rat. Neuroendocrinology 39, 236-244.

Goodman, R.L. \& Karsch, F.J. (1980) Pulsatile secretion of luteinizing hormone: differential suppression by ovarian steroids. Endocrinology 107, 1286-1290.

Gordon, K., Renfree, M.B., Short, R.V. \& Clarke, I.J. (1987) Hypothalamo-pituitary portal blood concentrations of $\beta$-endorphin during suckling in the ewe. $J$. Reprod. Fert. 79, 397-408.

Grandison, L., Fratta, W. \& Guidotte, A. (1980) Location and characterisation of opiate receptors regulating pituitary secretion. Life Sci. 26, 1633-1642.

Hossain, M.I., Lee, V.S., Clarke, I.J. \& O'Shea, J.D. (1979) Ovarian and luteal blood flow, and peripheral plasma progesterone levels in cycling guinea pigs. $J$. Reprod. Fert. 57, 167-174.

Jonas, H.A., Burger, H.G., Cumming, I.A., Findlay, J.K. \& de Kretser, D.M. (1975) Radioimmunoassay for luteinizing hormone-releasing hormone (LHRH): its application to the measurement of LHRH in ovine and human plasma. Endocrinology 96, 384-393.

Kalra, S.P. (1981) Neural loci involved in naloxone induced luteinizing hormone release: effects of a norepinephrine synthesis inhibitor. Endocrinology 109, 1805-1810.

Kalra, S.P. (1985) Neural circuits involved in the control of LHRH secretion: a model for estrous cycle regulation. J. Steroid Biochem. 23, 733-742.

Karsch, F.J., Cummins, J.T., Thomas, G.B. \& Clarke, I.J. (1987) Steroid feedback inhibition of pulsatile secretion of gonadotrophin-releasing hormone in the ewe. Biol. Reprod. (in press).

Kesner, J.S., Kaufman, J.-M., Wilson, R.C., Kuroda, G. \& Knobil, E. (1986) The effect of morphine on the electrophysiological activity of the hypothalamic luteinizing hormone-releasing hormone pulse generator in the rhesus monkey. Neuroendocrinology 43, 686-688.

Lamming, G.E., Moseley, S.R. \& McNeilly, J.R. (1974) Prolactin release in the sheep. $J$. Reprod. Fert. 40, 151-168.

Leadem, C.A. \& Kalra, S.P. (1985) Effects of endogenous opioid peptides and opiates in luteinizing hormone and prolactin secretion in ovariectomized rats. Neuroendocrinology 41, 342-352.

Leadem, C.A., Crowley, W.R., Simpkins, S.W. \& Kalra, S.P. (1985) Effects of naloxone on catecholamine and
LHRH release from the perifused hypothalamus of the steroid primed rat. Neuroendocrinology 40, 497-500.

Lee, V.W.K., Cumming, I.A., de Kretser, D.M., Findlay, J.K., Hudson, B. \& Keogh, E.J. (1976) Regulation of gonadotrophin secretion in rams from birth to social maturity. J. Reprod. Fert. 46, 1-6.

Lightman, S.L., Ninkovic, M., Hunt, S.P. \& Iversen, L.L. (1983) Evidence for opiate receptors on pituicytes. Nature, Lond. 305, 235-237.

Limonta, P., Piva, F., Maggi, R., Dondi, D., Motta, M. \& Martini, L. (1986) Morphine stimulates prolactin release in normal but not in castrated male rats. $J$. Reprod. Fert. 76, 745-750.

Malven, P.V., Bossut, D.F.B \& Diekman, M.A. (1984) Effects of naloxone and electroacupuncture treatment on plasma concentrations of LH in sheep. $J$. Endocr. 101, 75-80.

Martin, J.B., Tolis, W., Woods, I. \& Guyda, H. (1979) Failure of naloxone to influence physiological growth hormone and prolactin secretion. Brain Res. 168, 210-215.

Meites, J., Bruini, J.F., Van Vugt, D.A. \& Smith, A.F. (1979) Relation of endogenous opioid peptides and morphine to neuroendocrine functions. Life Sci. 24, 1325-1336.

Mioduszewski, R., Zimmermann, E. \& Critchlow, V. (1982) Effects of morphine dependence, withdrawal and tolerance on prolactin and growth hormone secretion in the rat. Life Sci. 30, 1343-1348.

Morley, J.E. (1981) The endocrinology of the opiates and opioid peptides. Metabolism 30, 1343-1348.

Moult, P.J.A., Grossman, A., Evans, J.M., Rees, L.H. \& Besser, G.M. (1981) The effect of naloxone on pulsatile gonadotrophin release in normal subjects. Clin. Endocr. 14, 321-324.

Orstead, K.M. \& Spies, H.G. (1986) Opioid peptide inhibition of the hypothalamic-pituitary axis in the rabbit. Proc. Ist Int. Congr. Neuroendocrinology, San Francisco, Abstr. 32.

Petraglia, F., Locatelli, V., Penalva, A., Cocchi, D., Genazzani, A.R. \& Muller, E.E. (1984) Gonadal steroid modulation of naloxone induced $\mathbf{L H}$ secretion in the rat. $J$. Endocr. 101, 33-39.

Piva, F., Maggi, R., Limonta, P., Motta, M. \& Martini, L. (1985) Effect of naloxone on luteinizing hormone, follicle-stimulating hormone, and prolactin secretion in the different phases of the estrous cycle. Endocrinology 117, 766-772.

Piva, F., Limonta, P., Maggi, R. \& Martini, L. (1986) Stimulatory and inhibitory effects of the opioids on gonadotropin secretion. Neuroendocrinology 42, 504-512.

Rasmussen, D.D., Liu, J.H., Wolf, P.L. \& Yen, S.S.C. (1983) Endogenous opioid regulation of gonadotrophin releasing hormone release from the human fetal hypothalamus in vitro. J. clin. Endocr. Metab. 57, 881-884.

Ropert, J.F., Quigley, M.E. \& Yen, S.S.C. (1981) Endogenous opiates modulate pulsatile luteinizing hormone release in humans. J. Clin. Endocr. Metab. 52, 583-585.

Sarkar, D.K. \& Yen, S.S.C. (1985) Changes in $\beta$ endorphin like immunoreactivity in pituitary portal blood during the estrous cycle and after ovariectomy in rats. Endocrinology 116, 2075-2079. 
Schulz, R., Wilhelm, A., Pirke, K.M., Gramsch, C. \& Herz, A. (1981) $\beta$-Endorphin and dynorphin control serum luteinizing hormone level in immature female rats. Nature, Lond. 294, 757-759.

Shaar, C.J., Frederickson, R.C., Dininger, N.B. \& Jackson, L. (1977) Enkephalin analogues and naloxone modulate the release of growth hormone and prolactin-evidence for regulation by an endogenous opioid peptide in the brain. Life Sci. 21, 853-860.

Shoupe, D., Montz, F.S. \& Lobo, R.A. (1985) The effect of estrogen and progestin on endogenous opioid activity in oophorectomized women. J. clin. Endocr. Metab. 60, 178-183.

Simantov, R. \& Snyder, S.H. (1977) Opiate receptor binding in the pituitary gland. Brain Res. 124, 178-184.

Sirinanthsinghji, D.J.S. \& Martini, L. (1984) Effects of bromocriptine and naloxone on plasma levels of prolactin, LH and FSH during suckling in the female rat: responses to gonadotrophin releasing hormone. $J$. Endocr. 100, 175-182.

Snowden, E.V., Khan-Dawood, F.S. \& Dawood, M.Y. (1984) The effect of naloxone on endogenous opioid regulation of pituitary gonadotropins and prolactin during the menstrual cycle. J. clin. Endocr. Metab. 59, 298-302.
Van Vugt, D.A., Bakst, G., Dyrenfurth, I. \& Ferin, M. (1983) Naloxone stimulation of luteinizing hormone secretion in the female monkey: influence of endocrine and experimental conditions. Endocrinology 113, 1858-1864.

Wamsley, J.K., Zarbin, M.A., Young, W.S. \& Kuhar, M.J. (1982) Distribution of opiate receptors in the monkey brain: an autoradiographic study. Neuroscience 7, 595-613.

Wardlaw, S.L., Wehrenberg, W.B., Ferin, M., Carmel, P.W. \& Frantz, A.G. (1980) High levels of $\beta$-endorphin in hypophyseal portal blood. Endocrinology 106, 1323-1326.

Wiesner, J.B., Koenig, J.I., Krulich, L. \& Moss, R.L. (1984) Site of action of $\beta$-endorphin induced changes in plasma luteinizing hormone and prolactin in the ovariectomized rat. Life Sci. 34, 1463-1473.

Wilkes, M.M. \& Yen, S.S.C. (1981) Augmentation by naloxone of efflux of LRF from superfused medial basal hypothalamus. Life Sci. 28, 2355-2359.

Received 4 March 1987 